\title{
TRIASSIC SANDSTONE PETROLOGY OF TASMANIA: EVIDENCE FOR A TASMANIA-TRANSANTARCTIC BASIN
}

\author{
by J.W. Collinson, J.T. Eggert and N.R. Kemp \\ (with eight text-figures and five tables)
}

COLLINSON, J.W., EGGERT, J.T. \& KEMP, N.R., 1990 (31:x): Triassic sandstone petrology of Tasmania: e vidence for a Tasmania-Transantarctic Basin. Pap. Proc. R. Soc Tasm. 124(1): 61-75. https://doi.org/10.26749/rstpp.124.1.61 ISSN 0080-4703. Byrd Polar Research Centre \& Department of Geology and Mineralogy, Ohio State University, Columbus, Ohio 43210, USA (JWC); Arco Alaska, Inc., P.O. Box 100360, Anchorage, Alaska 99510, USA (JTE); and Tasmanian Museum, GPO Box 1164M, Hobart, Tasmania, Australia 7001 (NRK).

Similar fluvial sequences of Triassic age occur in Tasmania and the Transantarctic Mountains of Victoria Land. The Tasmanian reference section at Poatina consists of Lower Triassic quartzose fluvial sandstones overlain by Miiciale and Upper Triassic volcaniclastic fluvial sandstones and shale containing coal. Similar, but less well-exposed seque nces, occur in many places in Tasmania and in southern Victoria Land. The hypothetical Tasmania-Transantarctic basin was similar in scale, configuration, and history to the Sydney foreland basin. Palaeocurrent data suggest that streams flowed along the axis of the basin from Antarctica to Tasmania. Lower Triassic sandstones were deposited by braided streams, but Middle and Upper Triassic stream deposits change from braided to meandering downstream toward Tasmania. Quartzose sandstones in the Lower Triassic were derived from northwestern Tasmania and the East Antarctic craton. The source of volcaniclastic sandstones in the Middle and Upper Triassic was a calcalkaline volcanic arc along the palaeo-Pacific margin. Key Words: Triassic, Tasmania, sandstone petrology, foreland basin, Antarctica, Gondwana.

\section{INTRODUCTION}

Prominent features of the landscape of central and eastern Tasmania are the dolerite-capped cliffs of Triassic sandstone along the margins of plateaus. Similar plateaus demonstrating the same stratigraphic relationships are characteristic of parts of the Transantarctic Mountains along the Ross Sea. The similarity between these landscapes on opposite sides of the Southern Ocean is striking. Are the similarities superficial or are the rocks that characterise these landscapes closely related to each other in a reconstructed Gondwanan supercontinent? The Jurassic dolerites have a similar chemical signature that is unique to Tasmania and the Transantarctic Mountains. The Triassic sandstones, representing ancient river systems, are by their nature more complex. Our objectives are (l) to document the sandstone petrology of the stratigraphic section at Poatina, which serves as a reference section for the Triassic of Tasmania, (2) to identify major patterns in Triassic fluvial deposition, as indicated by environments of deposition, palaeocurrent patterns, and composition of sandstones as related to changing source areas, and (3) to relate the Triassic of the Tasmania basin to its palaeogeographic setting near the palaeo-Pacific margin of the Gondwanan supercontinent.

Reviews of the Triassic System in Tasmania include Banks (1973, 1978), Hale (1962), and Forsyth $(1984,1989)$. Maps and explanatory reports published by the Department of Mines and unpublished theses by students at the University of Tasmania have also contributed much to the knowledge of Triassic rocks in various parts of the state.

Fieldwork for the project was carried out from February to May 1980, with field checks in August 1982 and April 1988. A detailed petrologic analysis of Triassic sandstones was reported by Eggert (1983) in a Master's thesis at the Ohio State University. Additional information on measured sections and crossbedding data is detailed in this thesis, which is on file in the library at the University of Tasmania. Sample numbers refer to a collection of thin sections and slabs from 228 surface samples and 37 core samples housed in the Department of Geology, University of Tasmania.

\section{STRATIGRAPHY}

A variety of stratigraphic names has been applied to the Triassic rocks in Tasmania. Deposited in a single large fluvial system, most lateral differences in rock type are local facies variations. These facies changes and the difficulty of correlating stratigraphic units across fault blocks have resulted in a proliferation of 
local stratigraphic names. Formal stratigraphic names for Triassic units have not been applied on quadrangle maps of the Department of Mines since 1963. Instead, letters descriptive of rock types or facies, such as TRp (quartz sandstone), TRm (muddy fluvial plain facies), TRs (quartz and lithicfeldspathic sandstone and interbedded mudstone and siltstone) are assigned (Forsyth 1984). While portraying a useful description of rock units sn quadrangle map, these informal names are in adequate for regional discussions such as this.

From a descriptive standpoint, all Triassic rocks in Tasnania can be grouped into two lithostratigraphic units. The lower unit is characterised by quartzose sandsione and the upper unit by volcanic lithic sandstone and shale with coal toward the top of the section. Following Banks \& Clarke (1973), we will use the nomenclature proposed by McKellar (1957) for the most complete and best exposed sequence of Triassic rocks in Tasmania, which is near Poatina along the northern margin of the Western Tiers (fig. 1). Because McKellar's descriptions and thicknesses are largely based on several cores, none of which fully penetrate the Triassic section, much confusion on the position of contacts at the surface exists. A proposal under consideration by the Department of Mines (S.M. Forsyth, personal communication) to obtain a complete core from a single borehole would be a great contribution to the knowledge of Tasmanian geology. The extensive

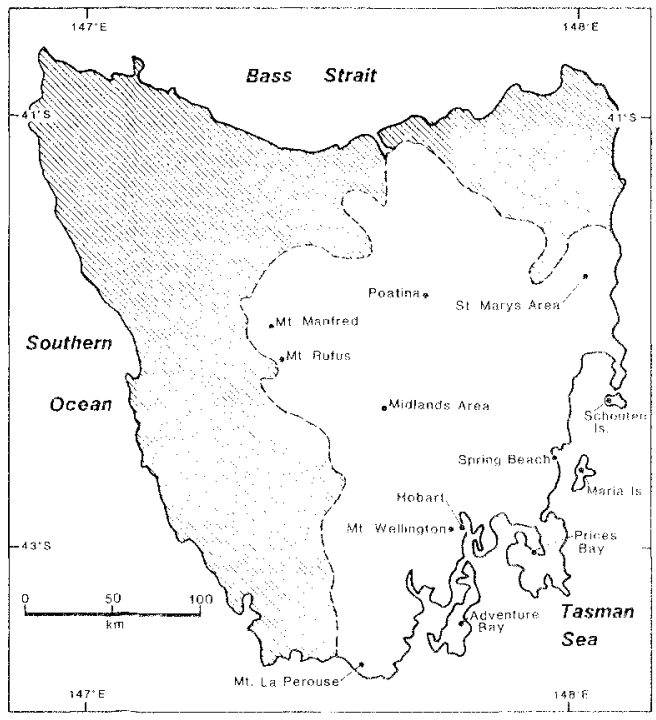

FlG, I Map of Tasmania showing localities referred to in the text. Diagonal pattern outside of the area of known Triassic exposures. mapping and palynologic studies of lriassio rook underway by forsyth (e.g. 1984, 1984), which do summarised in Forsyth (1989), will centually loab to detaled correlations and perhaps a new strat graphic momenclature accptable to araybody. A betles knowledge of the microllomal souncence in Tasmania is essential to the intumetalion d micofloras in Antarctica. Secions in the Transanarefic Mountains may be hetter exposed but the intersity of lurassic intrusions hes seriously damaged the microtoral record (Collinson 1990b)

The Pameener Supergroup inchistes the Upper Caboniforous to Triassic sequenes Hanks 1973). The Upper Parmeener Supergroup comprises the uppermose Pemian and Triassic Cuvial deposits. The lower part, including the Uppor Permian and Lower Triassic, is composed predominanty of quartzose sandstone; the upper part, including the Middle and Upper Triassic, is dominated by shale and volcaniclastic sandstone. Coal occurs in both the Upper Permian and Upper Triassic. Late Permian floras are separated from Early Triassic microfloras by a widespread disconformity, with coal-bearing, somewhat feldsparhic sandstone below and more quartzose sandstone with rare cabonaceous material above. Biostratigraphio control is not sufficient to detemine whether this lithological break represents a hiatus across the Permian-Triassic boundary (Banks 1962. Banks \& Naqvi 1967). The youngest unit with Permian fossils is the "Upper Freshwater Sequence", which is generally referred to as the Cygnet Coal Measures. Banks \& Clarke (1987) interpreted these rocks to represent a sandy coastal plain sequence. In northeastern Tasmania, particularly in the area around $\mathrm{St}$ Marys, Middle Triassic fluvial sediments discon. formably overlie Upper Permian marine beds, indicating a hiatus (Tumer \& Calver 1987). Regional truncation of Pennian beds suggests slight tilting and erosion just before Middle Triassic deposition.

Mckellat (1957) assigned the following forma. fional names to the Triassic succestion exposed along the Westem Tiers (in asconding order), Ross Sandstone, Cluan Fomation. Tiers Fomation, and Brady Fomation. Although these fomations were originally based on cores, an excellen reference section, graphically depicted in figure 2 , is exposed along the Poatina highway ascending the Western Tiers (Banks \& Clarke 1973). This highway did not exist at the lime McKellar completed his work. The palynostratigraphy of this sequence is somewhat known from the work of Play ford (196.5) and can be correlated with other sequences in Tasmania (Forsyth 1984, 1989). 


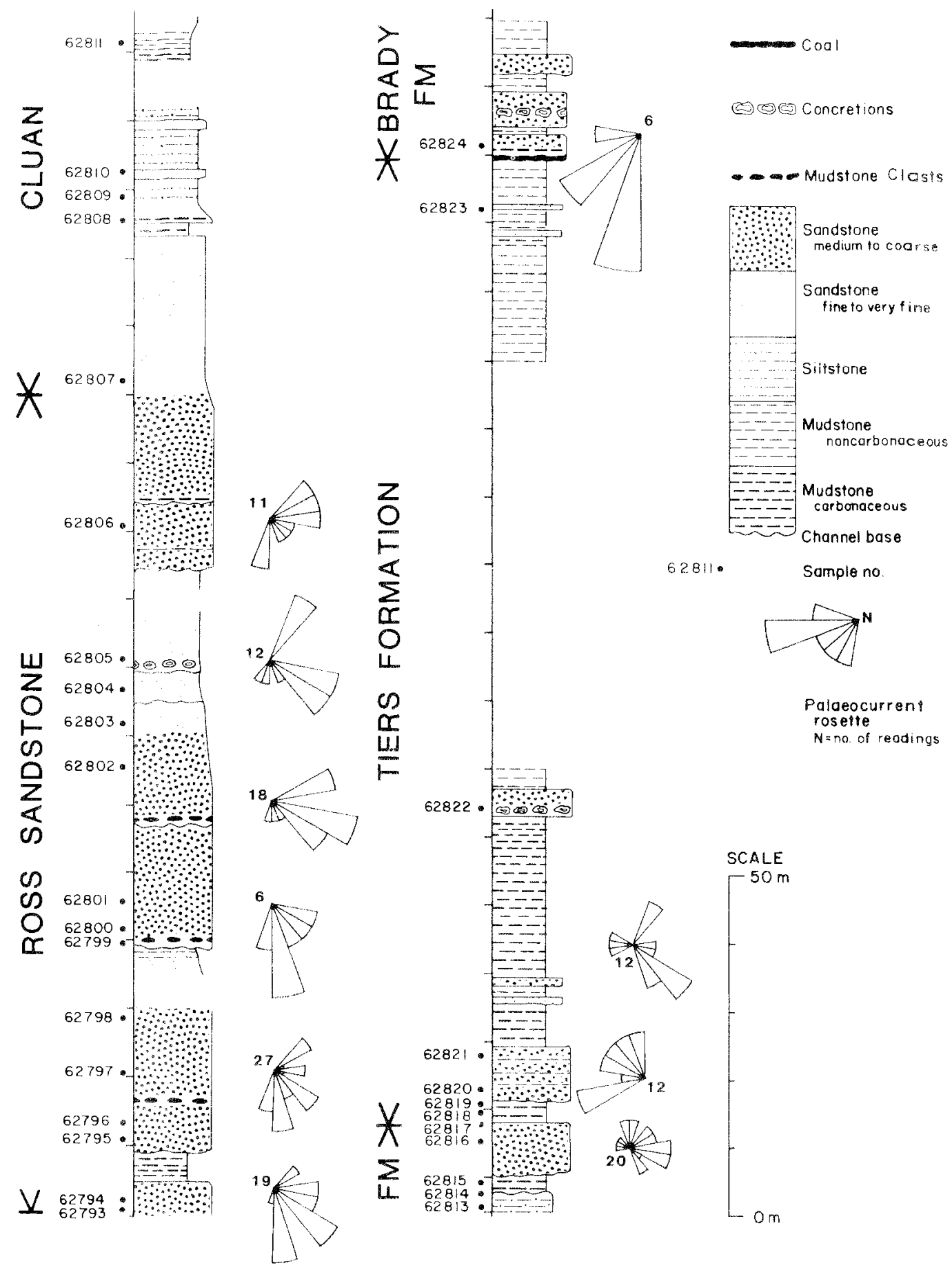

FIG. 2 - Triassic reference section along Western Tiers highway near Poatina. Sample numbers refer to the collections of the Department of Geology, Iniversity of Tasmania. Palaeocurrent rosettes are comparative; the frequencies counts for each class interval $\left(20^{\circ}\right)$ are converted to percentages of the total data set and these values are used as the radii lenght of the sectors. Plots were made by a computer program called "Sphere", whith is heing dereloped ho Phil Ingram. Sichool of Rarth Sciences, Macquarie University. 
McKellar (1957) described the Ross Sandstone as an "... impure, medium-grained quartz sandstone" marked by a line of cliffs along the face of the Tiers near Poatina. He noted that cores, which penetrated into the upper part of the formation, were entirely of sandstone and varied only in grain size. Our measured outcrop thickness of $170 \mathrm{~m}$ is less than the $650 \mathrm{ft}(200 \mathrm{~m})$ thickness reported by McKellar, which was based on $270 \mathrm{ft}(83 \mathrm{~m})$ of drill core plus an additional $380 \mathrm{fl}(117 \mathrm{~m})$ from "surface mapping".

The Ross Sandstone at Poatina disconformably overlies carbonaccous shale of the Jackey Shale, a correlate of the Cygnet Coal Measures. As noted by Forsyth (1984) in the Midlands area, the basal disconformity is no more pronounced than channel bases throughout the sequence. The formation is dominated by $5-20 \mathrm{~m}$ thick sandstone cycles separated by major channel scours. Mudstone clasts are commonly associated with these scours. Sandstones are coarse- to medium-grained, except near the tops of cycles where they may be finegrained. Thin lenticular mudstones occur locally along bedding surfaces. Large-scale trough crossbedding in sets averaging about $0.5 \mathrm{~m}$ thick predominates, but larger sets of tabular cross-

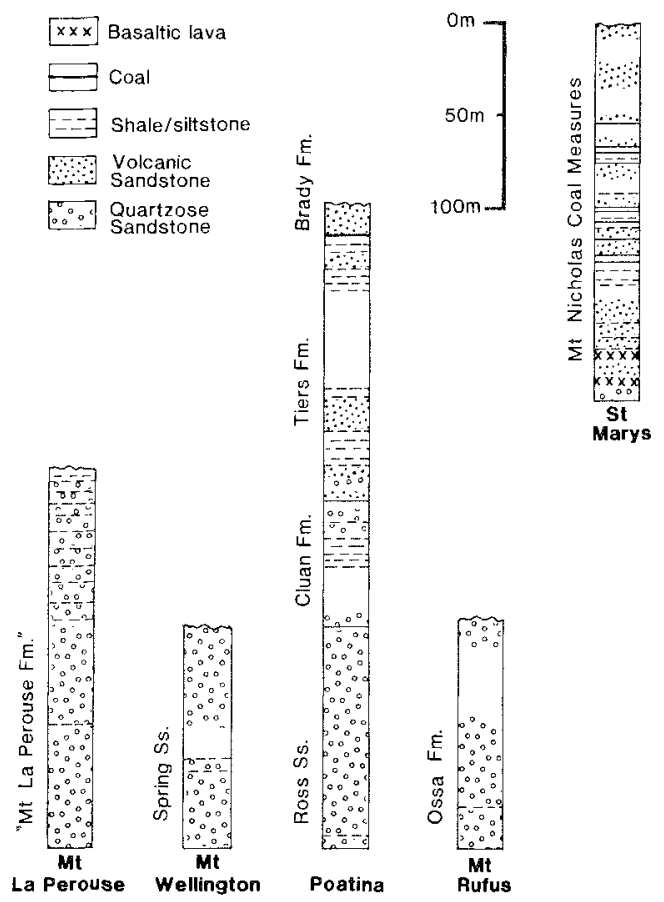

FIG. 3 - Selected stratigraphic columns in NEtrending traverse across Tasmania basin. bedding are also common. Cross-beds are commonly overturned. Finer-grained beds exhibit planar and ripple lamination.

The Ross Sandstone and its equivalents are early Early Triassic (Scythian) in age (Forsyth 1989). This resistant sandstone unit ranges between $100 \mathrm{~m}$ and $200 \mathrm{~m}$ thick, forming prominent cliffs throughout the Tasmania basin. The lower $125 \mathrm{~m}$ of the Triassic System (Davidson 1969) on M1 La Perouse and the Mountain Lodge Member of the Springs Sandstone on Mt Wellington (Banks 1978) fit the above description of the Ross Sandstone (see stratigraphic sections in figure 3). The Ossa Formation, which overlies the Upper Permian coal measures in the northwestern part of the Tasmania basin (e.g. Mt Rufus and Mt Manfred sections), is also similar, but generally coarser grained.

The name "Cluan Formation" was assigned to fine- to medium-grained quartzose sandstone interbedded with dark-grey shale and siltstone overlying the Ross Sandstone. McKellar reported a $460 \mathrm{ft}(142 \mathrm{~m})$ thickness based on cores, which is greater than the $113 \mathrm{~m}$ thickness that we measured along the Poatina highway. The lower $65 \mathrm{~m}$ is dominated by fine-grained quartzose sandstone. The upper $48 \mathrm{~m}$ contains some medium- to coarsegrained quartzose sandstone, but is dominated by fine- to medium-grained volcaniclastic sandstone. Carbonaceous mudstone and siltstone become more abundant upward in the section. Sandstone units are trough cross-bedded. The Cluan is assigned a late Early to early Middle Triassic (Scythian-Anisian) age based on the correlation suggested by Forsyth (1989). Fine-grained sandstones that form the top of Mt La Perouse also may be equivalent (fig. 3 ).

The Tiers Formation was described as a greygreen, khaki-weathering shale and "felspathic" sandstone, differing from the overlying Brady Formation in a lack of coal seams (McKellar 1957). Sandstone units are generally thinner than in the underlying formations and are interbedded with greenish-grey and grey carbonaceous siltstone and shale. Root casts and fossil plant material are common and coalified logs occur locally. The slopeforming, crumbly character of the formation is due to the predominance of mudstone and the easily weathered volcanic lithic component of the sandstone. Thin beds of quartzose sandstone occur near the base of the formation in the cores and in the transition between the Cluan and Tiers Formations along the Poatina highway. McKellar (1957) picked one of these quartzose units in the cores as the base of the Tiers, giving a total thickness of $280 \mathrm{ft}(86 \mathrm{~m})$ for the formation. This thickness is close to the $97 \mathrm{~m}$ thickness in the section along the Poatina highway, 
which is poorly exposed. The Tiers Formation is Middle Triassic (Anisian-Ladinian) in age (Forsyth 1989). Forsyth (1984) described Tiers-equivalent units on the Oatlands Sheet.

McKellar (1957) described the Brady Formation as consisting of fine- to medium-grained "felspathic" sandstone, dark-grey shale, and coal seams ranging in thickness from $0.5 \mathrm{ft}(15 \mathrm{~cm})$ to $5 \mathrm{ft}$ $(1.5 \mathrm{~m})$. The dominant rock types are greenish-grey and grey carbonaceous siltstone and shale. Sandstones are typically greenish-grey or greenishbrown, reflecting alteration of the volcanic component. The thicker sandstone bodies are channel-based and fine upward. Basal scours contain intraformational clay-pellet conglomerate and quartz, quartzite, and granitic clasts. Fossil plant material is common and silicified wood occurs locally. Based on the cores, McKellar (1957) noted a $540 \mathrm{ft}(166 \mathrm{~m})$ thickness for the formation. Only the lower part of the formation is well exposed along the Poatina highway (fig. 2). The base of the formation was selected at the base of the lowest coal seam. Sandstones in the Poatina cores are generally volcaniclastic. Sandstone samples from our measured section of the Mt Nicholas Coal Measures in the St Marys area (fig. 3), from the New Town Coal Measures in Hobart, and from coal-bearing beds on Schouten Island are indistinguishable from those of the equivalent Brady Formation. Forsyth (1984) has correlated these units with volcanic lithic arenite, lutite and coal measures in the Oatlands area. In the St Marys area two basaltic lava flows in the lower part of the Upper Parmeener Supergroup give radiometric ages of $233 \pm 5$ Ma (Calver \& Castleden 1981). Palynological analysis suggests an Anisian or Ladinian age for horizons above and below the basalts (Forsyth 1980). Tuffs near the top of the coal-bearing sequence near Bicheno in northeastern Tasmania have been dated at $214 \pm 1 \mathrm{Ma}$ (Bacon \& Everard 1981, Bacon et al., in Forsyth 1989), which places these beds within the Late Triassic according to the DNAG time-scale (Palmer 1983).

\section{TRIASSIC DEPOSITIONAL ENVIRONMENTS}

Although marine fossils occur in parts of the Permian sequence, no conclusive evidence of marine conditions has been reported in the Triassic sequence of Tasmania. Forsyth (1989) noted spinose acritarchs, but these could have been reworked. He also pointed out that sedimentary structures in some Middle Triassic rocks are similar to the deposits of tidally influenced estuaries. Trace fossils in the Upper Narrabeen Group of the Sydney basin suggest a marine influence in sandstones deposited under fluvially dominated estuarine conditions (Thann Naing, Macquarie University, written communication, 1989). Although similar trace fossils have not been reported in the Triassic of Tasmania, they could easily have been overlooked, as they were in the comparatively well-studied Sydney basin.

The predominance of channel-form sandstones and the occurrence of terrestrial vertebrate fossils (Cosgriff 1974, Camp \& Banks 1978) in the Ross Formation suggest predominantly fluvial conditions. The multistorey nature of sandstone units and the paucity of fine-grained flood-plain deposits support the conclusion that these represent braided stream deposits. Local mudstone-dominated intervals have been interpreted as lacustrine and flood-plain deposits (Forsyth 1984, 1989). Lateral accretion surfaces, apparent in at least one outcrop in the upper Cluan Formation, highly variable palaeocurrent data, and a predominance of finegrained beds suggest a meandering stream environment for the rest of the Triassic section. The generally fining-upward nature of the sequence is probably related to such factors as erosive lowering of the source area and the corresponding reduction in gradient, and a change to more humid conditions as indicated by the preservation of organic matter and coal.

\section{PALAEOCURRENT DIRECTIONS}

Palaeocurrent directions for 11 localities of the Ross Sandstone and its equivalents are shown in figure 4. A more complete listing of palaeocurrent data is shown in table 1.

The resistant Ross Sandstone is the only Triassic unit in which palaeocurrent data are easily gathered regionally. Dispersal directions are consistently toward the southeast quadrant except along the central east coast (Spring Beach, Schouten Island, Maria Island), where they swing toward the east. The low variability of directions at each locality and over the region is consistent with the interpretation that the Ross Sandstone represents low sinuosity braided stream deposits on a southeasterly dipping palaeoslope. Palaeocurrent directions in the reference section at Poatina are generally in the southeast quadrant throughout the Ross Sandstone, but show increasing variability upward as the sequence becomes finer grained. Readings from the overlying volcaniclastic upper Cluan, Tiers and Brady Formations vary greatly. Forsyth (1984) 


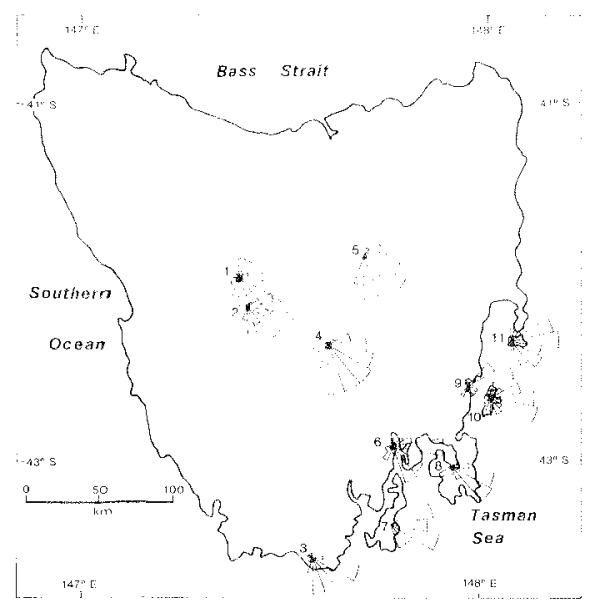

FIG. 4-Map of Tasmania showing palaeocurrent rosettes for the Ross Sandstone and equivalent units. Localities from E, W are: (1) Mt Rufus, (2) $M t$ Manfied, (3) Mt La Perouse, (4) Oatlands, (5) Poatina, (6) Mt Wellinglon, (7) Adventure Bay, (8) Prices Bay, (9) Spring Beach. (10) Maria Island, (II) Schouten Island. Compiled only for localities where data comprise 25 or more readings (see table I). The rosette for the Oatlands locality (4) was reconstructed from data presented by Forsyth (1984). Palacocurent rosettes are comparative; the frequencies counts for cach class interval $\left(20^{\circ}\right)$ are converted to percentages of the total data set and these values are used as the radii lengths of the sectors. Plots were made by "Sphere", as fig. 2.

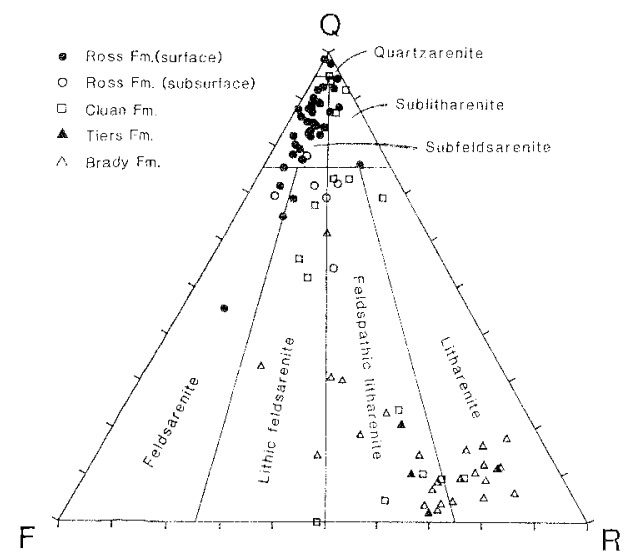

F/G. 5-Triangular diagram showing compositional differences between formations (Folk et al. 1970). noted a reversal from southeast to northwest in palaeocurrent directions between the quartzose sequence and the overlying lithic sandstone sequence in the Midlands. Directions in equivalent rocks in the S1 Marys area are highly scattered and do not give a preferred direction (Tumer \& Calver $1987\}$

\section{PETROGRAPHY}

Modal analyses of the detrital component of 91 fine. to medium-graned sandstone samples are listed in Lables 2 10 5 . These are compared in the triangular diagram (fig. 5). Samples for point counting were selected from the more than 300 samples and thin sections from throughout the Tasmania Basin. As is apparent at outcrops, sandstones from the lower part of the Triassic section are very different in composition from those in the upper part of the section. This change occurs abruptly in the Poatina section within the Cluan Formation with the introduction of volcanic grains (fig. 6). Quartzose sandstones dominate the Ross and lower Cluan Formations and their stratigraphic equivalents. Sandstones in the Upper Cluan, Tiers, and Brady Formations and their stratigraphic equivalents contain many of the same types of grains, which are, however, overwhelmed by the volcaniclastic component. Quartzose sandstones occur rarely in the upper sequence and are easily differentiated from those in the lower sequence by the presence of volcanic lithic grains.

\section{Ross and Lower Cluan Formations and Equivalents (Quartzose Sequence)}

The quartzose sandstones of the Ross and Cluan Formations and their equivalents are characterised by low ratios of plagioclase to tolal feldspar $(\mathrm{P} / \mathrm{F})$. polycrystalline quartz to total quartz (Qp/Q) and volcanic lithic fragments to total rock fragments ( V/ R). The average composition of sandstones in the Ross Fomation and its equivalents (table 2) falls into the subfeldsarenite field in the classification of Folk et al. (1970). As is apparent on the triangular plot (fig. 5), subsurtace samples contain a higher percentage of feldspar and rock fragments and fall into the lithic feldsarenite field. These components apparently have been removed by weathering. The average compositions of subsurface samples from the Ross and lower Cluan Formations are not significantly different, but they fall into different fields, lithic feldsarenite and feldspathic litharenite. 
TABLE 1

Palaeocurrent Data from Tasmania

\begin{tabular}{lllrrrr} 
Locality" & Formation & Age & N & VM & VS & SD \\
Poatina & Cluan & L Triassic & 50 & 567 & 20 & 90 \\
Poatina & Ross & L Triassic & 102 & 122 & 74 & 45 \\
Mi Manfred & Ossa & L Triassic & 33 & 117 & 82 & 37 \\
Mt Rufus & Ossa & L Triassic & 53 & 118 & 56 & 63 \\
Woods Quoin & Ross & L Triassic & 18 & 113 & 88 & 31 \\
New Norfolk & Ross & L Triassic & 20 & 139 & 45 & 80 \\
York Plains & "Volc. lithic" & U Triassic & 23 & 87 & 22 & 91 \\
Schouten ls. & Ross & L Triassic & 53 & 102 & 74 & 46 \\
Spring Beach & Ross & L Triassic & 32 & 82 & 69 & 52 \\
Maria ls. & Ross & L Triassic & 32 & 85 & 81 & 37 \\
Mt Wellington & Springs & L Triassic & 63 & 116 & 56 & 63 \\
Prices Bay & Ross & L Triassic & 56 & 127 & 74 & 48 \\
Adventure Bay & Ross & L Triassic & 29 & 102 & 90 & 26 \\
Mt La Perouse & "La Perouse" & L Triassic & 59 & 114 & 64 & 34 \\
\hline
\end{tabular}

$\mathrm{N}=$ number of readings, $\mathrm{VM}=$ vector mean in degrees, $\mathrm{VS}=$ vector strength in percent, $\mathrm{SD}=$ azimuth standard deviation in degrees.

* Localities shown on figure 1, except for Woods Quoin, New Norfolk and York Plains, which are in the Midlands area. $\dagger$ Not a meaningful direction.

Monocrystalline quartz grains are mostly subrounded to subangular and equant. Two-thirds are nonundulose. Included are (l) euhedral biotite or Inuscovite, (2) disseminated, randomly oriented rutile needles, (3) stubby light-green apatite, (4) rounded vacuole-shaped or euhedral tourmaline, and (5) euhedral zircon. Non-mineral inclusions include common curvilinear vacuole trains and abundant disseminated vacuoles. Some monocrystalline quartz grains with abundant vacuole inclusions also have vermicular chlorite inclusions; these grains are presumably of vein origin.

Polycrystalline quartz grains display elongated original crystals that have polyhedral outlines, smooth crystal-crystal boundaries, and many show interfacial angles of $120^{\circ}$ at triple junctions of crystal unit boundaries. Elongate polycrystalline quartz grains are subangular to angular, whereas equant grains are more commonly subrounded to well rounded. Mineral inclusions are less abundant than in monocrystalline grains and are primarily randomly oriented muscovite or biotite.

Feldspar grains include microcline and orthoclase. Plagioclase grains are typically sodic andesine $\left(\mathrm{An}_{30-4)}\right)$. One-third or tewer of all plagioclase grains are Carlsbad-twinned. They are commonly subrounded. No zoned grains were observed.
Rock fragments, in order of decreasing relative abundance, include: (1) sedimentary-metasedimentary grains, and subordinate (2) volcanichypabyssal, (3) metamorphic, and (4) plutonic varieties. Sedimentary rock fragments are subrounded to well-rounded mudstone and siltstone of intrabasinal origin, and slate. Only a few volcanic rock fragments were identified and none were vitric; these were probably derived from older volcanic rocks. Metamorphic rock fragments are low in relative abundance, but are ubiquitous. Most conımon are schistose polycrystalline quartz grains composed of elongate original host crystals with crenulated and sutured crystal-crystal boundaries; muscovite, biotite, or chlorite inclusions are oriented parallel or subparallel to the long axes of quartz grains. Plutonic rock fraginents are rare and identified by micrographic or myrmekitic textures.

Minor constituents include mica concentrated on bedding planes. Biotite is more common than muscovite. The more abundant heavy minerals are angular, isotropic garnet and well-rounded to subrounded tourmaline grains that are pleochroic in green, dark blue, brown and zoned green-brown. Other heavy minerals include well-rounded or euhedral zircon, zoisite, clinozoisite and subrounded magnerite-ilmenite grains. 


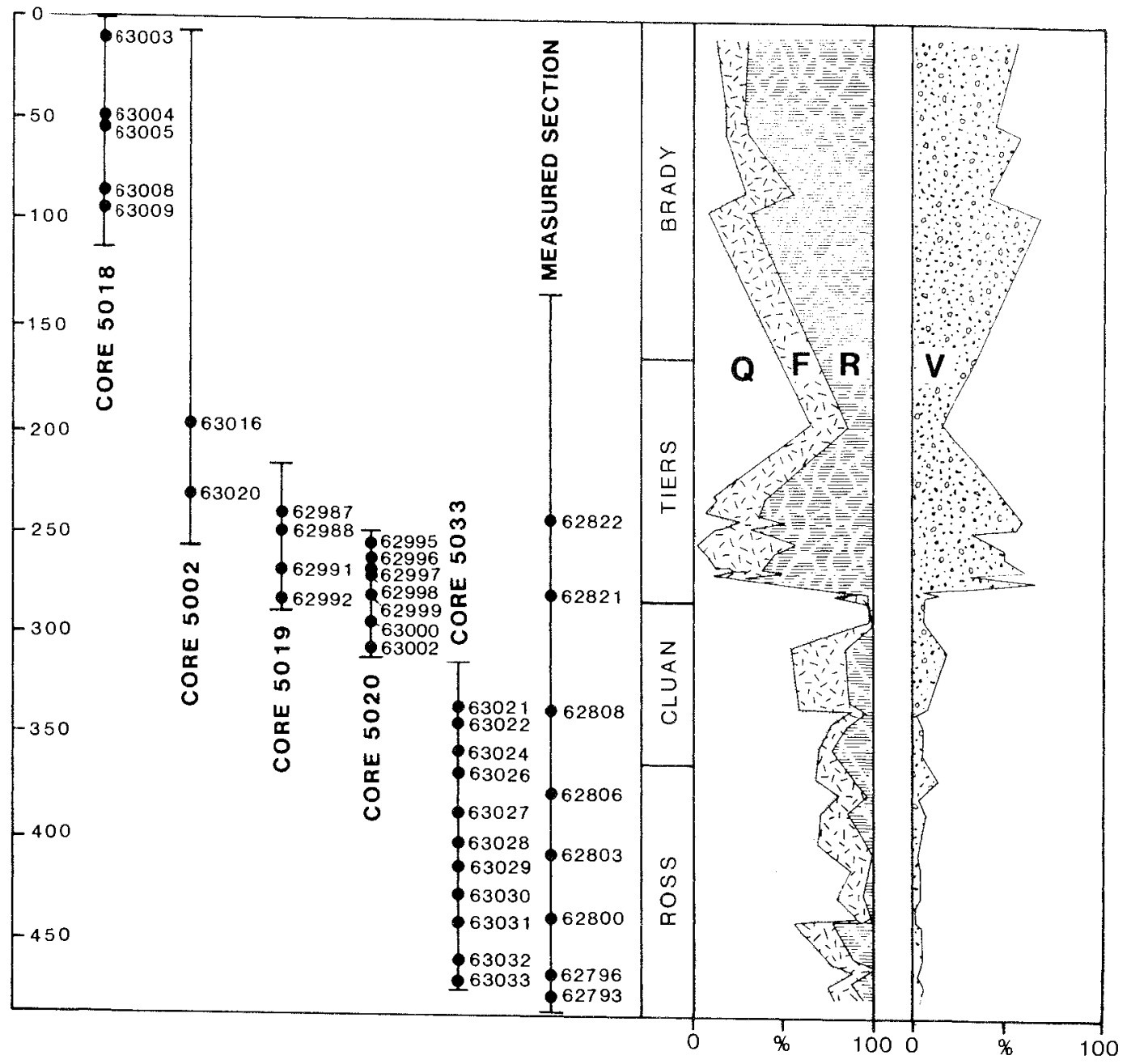

FIG. 6 - Graphic presentation of modal analyses of Poatina cores and measured section, showing percentages of quartz $(Q)$, feldspar $(F)$ and rock fragments $(R)$ in column on left and percentage of volcanic (V) rock fragments compared to total rock fragments in column on right. Sample numbers refer to the collections of the Department of Geology, University of Tasmania.

Matrix and cement include small amounts of clay $(2-3 \%)$, particularly in core samples. Clay cement consists of illite, kaolinite and minor chlorite and smectite and occurs as (I) recrystallised detrital mudstone fragments and clay matrix, (2) rims on detrital grains, (3) pore-lining and pore-filling cement, (4) feldspar grain replacements. Calcite occurs locally as anhedral intergranular pore-lining cement and as a feldspar and quartz grain replacement.

\section{Upper Cluan, Tiers, Brady Formation and Equivalents (Volcaniclastic Sequence)}

Volcaniclastic sandstones are characterised by abundant volcanic rock fragments. In contrast to the underlying quartzose sequence, volcaniclastic sandstones have high ratios of plagioclase to total feldspar $(\mathrm{P} / \mathrm{F})$, volcanic rock fragments to total rock fragments $(\mathrm{V} / \mathrm{R})$, and polycrystalline quartz to total quartz $(\mathrm{Qp} / \mathrm{Q}))$. The average compositions of the 
TABLE 2

Modal Analyses of Ross Sandstone and Equivalent Units*

\begin{tabular}{|c|c|c|c|c|c|c|c|c|c|}
\hline \multirow{2}{*}{$\begin{array}{l}\text { Locality } \\
\text { Mt Rufus }\end{array}$} & \multirow{2}{*}{$\begin{array}{r}\text { Sample } \\
62785\end{array}$} & \multirow{2}{*}{$\begin{array}{l}\text { Formation } \\
\text { Ossa }\end{array}$} & \multirow{2}{*}{$\begin{array}{l}\text { Classification } \\
\text { Subfeldsarenite }\end{array}$} & \multicolumn{3}{|c|}{$\begin{array}{l}\text { Q } \quad \mathrm{F} \quad \mathrm{R} \\
\text { (expressed as \% of } \\
\text { framework grains) }\end{array}$} & \multirow{2}{*}{\multicolumn{2}{|c|}{$\begin{array}{cc}\begin{array}{c}\mathbf{P} / \mathbf{F} \quad \mathbf{V} / \mathbf{R} \\
\text { (expressed as }\end{array} \\
0.33 \quad 0.27\end{array}$}} & \multirow{2}{*}{$\begin{array}{r}\mathrm{Qp}_{\mathrm{p}} \\
\text { ratio\% } \\
0.0\end{array}$} \\
\hline & & & & 89.3 & 7.0 & 3.7 & & & \\
\hline Mt Rufus & $\$ 2784$ & Ossa & Subfeldsarenite & 78.2 & 17.5 & 4.3 & 0.11 & 0.61 & 0.05 \\
\hline Mt Rufus & 62783 & Ossa & Subleldsarenite & 82.0 & 12.3 & 5.7 & 0.08 & 0.23 & 0.11 \\
\hline Mt Rufus & 62782 & Ossa & Subfeldsarenite & 86.3 & 12.0 & 1.7 & 0.25 & 0.80 & 0.05 \\
\hline Mt Rufus & 2781 & Ossá & Subfeldsarenite & 80.3 & 16.0 & 3.7 & 0.14 & 0.27 & 0.04 \\
\hline Mt Rufus & 2788 & Ossa & Lithic feldsarenite & 68.7 & 22.0 & 9.3 & 0.42 & 0.17 & 0.05 \\
\hline Mt La Peroute & $\therefore 2764$ & La Perouse & Subfeldsarenite & 84.4 & 10.0 & 5.6 & 0.16 & 0.82 & 0.01 \\
\hline Mt La Perous & 62761 & La Perouse & Subfeldsarenite & 92.0 & 6.0 & 2.0 & 0.66 & 0.15 & 0.01 \\
\hline Mt La Perolis: & 02760 & La Perouse & Subfeldsarenite & 88.0 & 9.7 & 2.3 & 0.20 & 0.85 & 0.01 \\
\hline Mt La Perouss & 62759 & La Perouse & Subfeldsarenite & 88.3 & 9.0 & 2.7 & 0.18 & 0.62 & 0.04 \\
\hline Mt La Perous: & 62773 & La Perouse & Subfeldsarenite & 83.3 & 11.7 & 5.0 & 0.85 & 0.46 & 0.13 \\
\hline Scouten Is. & 62881 & Unnamed & Sublitharenite & 76.1 & 5.7 & 18.2 & 0.52 & 0.42 & 0.00 \\
\hline Schouten Is. & 62887 & Unnamed & Quartzarenite & 97.6 & 0.8 & 1.6 & 0.50 & 1.00 & 0.08 \\
\hline Schouten Is. & 62890 & Unnamed & Subfeldsarenite & 85.2 & 11.4 & 3.4 & 0.00 & 0.40 & 0.08 \\
\hline Schouten Is. & 62894 & Unnamed & Quartzarenite & 98.5 & 1.5 & 0.0 & 0.00 & 0.00 & 0.00 \\
\hline Mt Manfred & 628.57 & Ossa & Subfeldsarenite & 87.9 & 11.7 & 0.4 & 0.09 & 0.00 & 0.10 \\
\hline Mt Manfred & 62589 & Ossa & Subfeldsarenite & 92.6 & 4.7 & 2.7 & 0.09 & 0.00 & 0.03 \\
\hline Mt Manfred & 62860 & Ossa & Feldsarenite & 45.4 & 46.8 & 7.8 & 0.50 & 0.43 & 0.08 \\
\hline Mt Manfred & 62862 & Ossa & Subfeldsarenite & 82.2 & 15.4 & 2.4 & 0.24 & 0.00 & 0.38 \\
\hline Midway point & 62856 & Knocklofty & Feldsarenite & 71.5 & 23.2 & 5.3 & 0.13 & 0.21 & 0.04 \\
\hline Mt Knocklofty & 62973 & Knocklofty & Subfeldsarenite & 82.4 & 10.3 & 7.3 & 0.45 & 0.13 & 0.06 \\
\hline Mt Knocklofty & 62972 & Knocklofty & Sublitharenite & 87.2 & 6.0 & 6.7 & 0.44 & 0.10 & 0.03 \\
\hline Mt Knocklofty & 62971 & Knocklofty & Sublitharenite & 92.3 & 2.7 & 5.0 & 0.75 & 0.40 & 0.04 \\
\hline Mt Knocklofty & 62969 & Knocklofty & Subfeldsarenite & 85.0 & 10.3 & 4.7 & 0.74 & 0.35 & 0.07 \\
\hline Mt Knocklofty & 62966 & Knocklofty & Subfeldsarenite & 87.3 & 9.4 & 3.4 & 0.50 & 0.11 & 0.02 \\
\hline Mt Knocklofty & 62965 & Knocklofty & Lithic feldsar. & 65.0 & 25.9 & 9.1 & 0.57 & 0.16 & 0.06 \\
\hline Mt Wellington & 62945 & Springs & Sublitharenite & 94.4 & 1.0 & 4.6 & 0.00 & 0.07 & 0.04 \\
\hline Mt Wellington & 62944 & Springs & Subfeldsarenite & 84.0 & 8.7 & 7.3 & $0 . \dot{2} 3$ & 0.36 & 0.04 \\
\hline Mt Wellington & 62943 & Springs & Sublitharenite & 87.3 & 6.0 & 6.7 & 0.11 & 0.10 & 0.06 \\
\hline Mt Wellington & 62942 & Springs & Sublitharenite & 88.3 & 3.7 & 8.0 & 0.36 & 0.08 & 0.02 \\
\hline Mt Wellington & 62941 & Springs & Subfeldsarenite & 90.3 & 7.7 & 2.0 & 0.65 & 0.83 & 0.04 \\
\hline Poatina & 62806 & Ross & Subfeldsarenite & 79.4 & 15.6 & 5.0 & 0.04 & 0.27 & 0.06 \\
\hline Poatina & 62803 & Ross & Subfeldsarenite & 75.8 & 20.2 & 4.0 & 0.20 & 0.25 & 0.04 \\
\hline Poatina & 62800 & Ross & Subfeldsarenite & 89.1 & 7.0 & 3.9 & 0.23 & 0.17 & 0.09 \\
\hline Poatina & 62796 & Ross & Subfeldsarenite & 89.1 & 8.6 & 2.3 & 0.23 & 0.43 & 0.04 \\
\hline Poatina & 62793 & Ross & Subfeldsarenite & 77.1 & 16.3 & 6.6 & 0.32 & 0.25 & 0.07 \\
\hline Poatina core & 63027 & Ross & Lithic feldsarenite & 69.0 & 15.7 & 15.3 & 0.46 & 0.47 & 0.11 \\
\hline Poatina core & 63028 & Ross & Feldsarenite & 69.4 & 25.3 & 5.3 & 0.36 & 0.43 & 0.10 \\
\hline Poatina core & 63029 & Ross & Subfeldsarenite & 82.7 & 12.3 & 5.0 & 0.32 & 0.66 & 0.08 \\
\hline Poatina cor? & 63030 & Ross & Subfeldsarenite & 78.0 & 15.0 & 7.0 & 0.57 & 0.42 & 0.18 \\
\hline Poatina core & 63031 & Ross & Fcldsp. litharenite & 54.0 & 21.7 & 24.3 & 0.60 & 0.21 & 0.14 \\
\hline Poatina core & 63032 & Ross & Lithic feldsarenite & 71.6 & 16.7 & 11.7 & 0.78 & 0.22 & 0.33 \\
\hline Poatina core & 63033 & Ross & Feldsp. litharenite & 72.0 & 12.0 & 16.0 & 0.83 & 0.39 & 0.21 \\
\hline Average of sur & ace sampl & & Subfeldsarenite & 84.2 & 11.2 & 4.6 & 0.27 & 0.36 & 0.06 \\
\hline Average of sub & urface sal & & Lithic feldsarenite & 71.0 & 17.0 & 12.1 & 0.56 & 0.40 & 0.16 \\
\hline Average of all & amples & & Subfeldsarenite & 81.6 & 12.4 & 6.0 & 0.32 & 0.34 & 0.08 \\
\hline
\end{tabular}

$\mathrm{Q}=$ quartz, $\mathrm{F}=$ feldspar, $\mathrm{R}=$ rock fragment, $\mathrm{P} / \mathrm{F}=$ plagioclase $/$ total feldspar, $\mathrm{V} / \mathrm{R}=$ volcanic rock fragment $/$ total rock fragment, $\mathrm{Qp} / \mathrm{Q}=$ polycrystalline/total quartz.

* Based on 300 or more data points for each sample. 
TABLE 3

Modal Analyses of Cluan Formation*

\begin{tabular}{|c|c|c|c|c|c|c|c|c|c|}
\hline Lecality & Sample & Formation & Classification & \multicolumn{3}{|c|}{$\begin{array}{l}\text { (expressed as \% af } \\
\text { framework gerins) }\end{array}$} & \multicolumn{3}{|c|}{ (exponsen as ratos $)$} \\
\hline Poatina & 62808 & Cluan & Sublitharenite & 87.2 & 49 & 8.0 & $0:$ & 112 & 0.06 \\
\hline Poatina core & 62999 & Cluan & Feldsp. litharenite & 73.1 & 12.3 & 14.6 & $C: \therefore$ & .75 & 0.09 \\
\hline Poatina core & 62992 & Cluan & Sublitharenite & 92.0 & 0.6 & 7.4 & $(n)$ & 0.13 & 0.04 \\
\hline Poatina core & 63000 & Cluan & Quartzarenite & 95.0 & 2.3 & 2.7 & $1: 14$ & 0.75 & 0.04 \\
\hline Poatina core & 63002 & Cluan & Lithic arkose & 52.0 & 27.7 & 20.3 & 53 & 0.72 & 0.23 \\
\hline Poatina core & 63021 & Cluan & Lithic arkose & 56,0 & 27.3 & 16.7 & .61 & 0.26 & 0.17 \\
\hline Poatina core & 63022 & Cluan & Feldisg. liblatenite & 73.0 & 9.3 & $17 \%$ & 50 & 0.32 & 0.11 \\
\hline Poatina core & 63024 & Cluan & Litharenite & 690 & 4.7 & 26.3 & 150 & 0.22 & 0.14 \\
\hline Poatina core & 63026 & Cluan & Lithic arkose & 67.3 & 18.7 & 13.9 & 0.27 & 0.82 & 0.17 \\
\hline \multicolumn{4}{|c|}{ Average composition } & 73.8 & 12.0 & 14.2 & 0.33 & 0.45 & 0.12 \\
\hline
\end{tabular}

* Abbreviations and explanations as table 2.

upper and lower Cluan Formation (table 3) both fall into the feldspathic litharenite field, but they are generally at opposite ends (fig. 5). The average compositions of the Tiers and Brady sandstones (table 4) falls into the litharenite field. Surface and core samples are not significantly different.

Rock fragments are dominated by epiclastic volcanic-hypabyssal grains. These are equant or elongate and subangular to well rounded, with a few angular grains. Grains are intermediate to felsic in composition and are identified by microlitic plagioclase feldspar inclusions that result in felted and pilotaxitic textures. Plagioclase feldspar microlites occur in a light to dark-brown or browngreen matrix. The matrix is in some cases devitrified, chloritised or oxidised. Aphanitic fragments that have relict fabrics resembling those of feldspar microlites in devitrified glass groundmass were identified as volcanic fragments. Darkbrown fragments of vitric crystalline tuffaceous material occur sparsely, and are recognised by bubble-wall textures characteristic of volcanic glass shards. Basaltic fragments are associated with Triassic basalt flows in the Mt Nicholas Coal Measures north of St Marys. Other rock fragments include small but consistent proportion of schistose grains containing biotite, muscovite, or chlorite. Plutonic grains, typically with intergrowths of monocrystalline quartz with orthoclase, plagioclase, or microcline, are sparse but more abundant than in the underlying quartzose sequence.

Feldspars are dominated by plagioclase, ranging in composition from calcic oligocinse to sodic andesine $\left(\mathrm{An}_{35}\right)$. These are equant to longate and angular to subrounded. The grains are typically fresh, but some contain vacuoles. Many grains show albite twinning, and about one-third of these display Carlsbad twinning as well. Many display well developed oscillatory zoning. Microcline, orthoclase and microperthite occur in relatively minor amounts.

Quartz grains occur in telatively low abundance in most samples from the Tiers Formation and equivalents. A notable difference is the presence of angular to subrounded volcanic quartz grains. These exhibit straight extinction, display hpyramidal cross sections, and some are embayed.

Minor (onstituents make up less than $1 \%$ of total framework grains. Of these, biotite is the nost abundant, occurring mainly along bedding planes and cross-bedding laminae.

Matrix and cement comprise clay matri (typically about $5 \%$, calcite and chiy cements and less commonly famontite and guartz. Calste occurs extensively as an anhedral intergrantalar pre-filling cement and as a replacement mineral in piggioclase, quartz and volcanic rock frazments. Clay cements consist of chlorite and smectite with subordinate amounts of illite and kaolinile. Clay cement abundances are the opposite of those in the underlying quarloose sequence. Clay cements occur as (1) pore-lining. (2) hydration rims on plagioclase grains and volcanic lithic fragments, and (3) grain replacements. Authigenic quart is present 
TABLE 4

Modal Analyses of Tiers and Brady Formation and Equivalenc Units*

\begin{tabular}{|c|c|c|c|c|c|c|c|c|c|}
\hline Locality & Sample & Formation & Classification & \multicolumn{3}{|c|}{$\begin{array}{l}\text { (expressed as } \% \text { of } \\
\text { lramework grains) }\end{array}$} & \multicolumn{3}{|c|}{ (expressed as ratios) } \\
\hline St Marys & 62848 & Mi Nicholas & Litharenite & 15.5 & 15.2 & 64.3 & 0.81 & 0.71 & 0.12 \\
\hline St Marys & 62847 & Mt Nicholas & Litharenite & 16.4 & 11.6 & 71.9 & 0.58 & 0.78 & 0.29 \\
\hline St Marys & 62846 & Mt Nicholas & Feldspathic litharenite & 4.0 & 25.7 & 703 & 0.85 & 0.82 & 0.08 \\
\hline St Marys & 62845 & Mt Nicholas & Feldspathic litharenite & 2.7 & 27.0 & 70.3 & 0.96 & 0.80 & 0.25 \\
\hline St Marys & 62844 & Mt Nicholas & Feldspathic litharenite & 3.7 & 29.0 & 67.3 & 0.91 & 0.68 & 0.09 \\
\hline St Marys & 02843 & Mi Nicholas & Feldspathic litharenite & 30.9 & 33.6 & 35.5 & 0.72 & 0.65 & 0.03 \\
\hline St Marys & 62841 & Mi Nichotas & Peldspathic litharenite & 30.3 & 31.7 & 38.0 & 0.93 & 0.61 & 002 \\
\hline St Marys & 62839 & Mt Nicholas & Feldspathic litharenite & 18.7 & 34.0 & 47.3 & 0.96 & 0.66 & 0.08 \\
\hline St Marys & 62838 & Mt Nicholas & Litharenite & 9.3 & 19.3 & 71.3 & 1.00 & 0.65 & 0.14 \\
\hline Si Marys & 62837 & Mt Nicholas & Feldspathic litharenite & 14.4 & 24.7 & 60.9 & 0.98 & 0.86 & 0.09 \\
\hline St Marys & 62836 & Mt Nicholas & Litharenite & 10.6 & 15.9 & 73.5 & 1.00 & 0.92 & 0.03 \\
\hline St Marys & 62833 & Mt Nicholas & Lithic feldsarenite & 33.3 & 45.7 & 21.0 & 0.92 & 0.93 & 0.14 \\
\hline St Marys & 62831 & Mt Nicholas & Feldspathic litharenite & 14.3 & 44.3 & 41.3 & 0.99 & 0.95 & 0.01 \\
\hline St Marys & 62829 & Mt Nicholas & Litharenite & 5.3 & 16.9 & 77.8 & 0.98 & 0.99 & 0.31 \\
\hline Hobart & 62939 & New Town & Litharenite & 6.3 & 10.6 & 83.1 & 0.71 & 0.62 & 0.36 \\
\hline Hobart & 62938 & New Town & Feldspathic litharenite & 8.7 & 24.0 & 67.3 & 0.8 .5 & 0.96 & 0.19 \\
\hline Hobart & 62937 & New Town & Feldspathic litharenite & 7.0 & 25.9 & 67.1 & 0.91 & 0.74 & 0.19 \\
\hline Schouten Is. & 62883 & Unnamed & Litharenite & 11.5 & 11.2 & 77.2 & 0.94 & 0.81 & 0.69 \\
\hline Schouten Is. & 62884 & Unnamed & Litharenite & 18.0 & 6.2 & 75.7 & 1.00 & 0.66 & 0.25 \\
\hline Poalina core & 63003 & Brady & Litharenite & 9.0 & 14.7 & 76.3 & 0.65 & 0.65 & 0.37 \\
\hline Poatina core & 63004 & Brady & Litharenite & 11.8 & 10.5 & 77.7 & 0.80 & 0.48 & 0.47 \\
\hline Poatina core & 63005 & Brady & Litharenite & 12.3 & 13.4 & 74.3 & 0.81 & 0.70 & 0.38 \\
\hline Poatina core & 63008 & Brady & Feldspathic litharenite & 23.3 & 26.7 & 50.2 & 0.53 & 0.65 & 0.16 \\
\hline Poatina core & 63009 & Brady & Litharenite & 4.5 & 23.3 & 72.4 & 0.72 & 0.86 & 0.07 \\
\hline Poatina core & 63016 & Tiers & Feldspathic litharenite & 61.6 & 19.2 & 19.2 & 0.62 & 0.58 & 0.17 \\
\hline Poatina & 62822 & Tiers & Feldspathic litharenite & 20.9 & 24.8 & 54.2 & 0.87 & 0.78 & 0.14 \\
\hline Poatina core & 63020 & Tiers & Feldspathic litharenite & 10.4 & 28.2 & 61.4 & 0.69 & 0.75 & 0.35 \\
\hline Poatina core & 62987 & Tiers & Feldspathic litharenite & 2.1 & 29.0 & 68.9 & 0.74 & 0.81 & 0.16 \\
\hline \multirow{2}{*}{\multicolumn{3}{|c|}{$\begin{array}{l}\text { Average for Brady and equivalents } \\
\text { Average for Tiers }\end{array}$}} & Litharenite & 13.4 & 22.5 & 64.1 & 0.85 & 076 & 0.20 \\
\hline & & & Feldspathic litharenitc & 11.1 & 27.3 & 61.5 & 0.77 & 0.78 & 0.22 \\
\hline
\end{tabular}

* Abbreviations and explanations as table 2.

in minor amounts as a porefilling cement. Laumontite occurs as pore-filling cement and grain replacements of plagioclase and volcanic rock fragments.

\section{PROVENANCE}

Quartz grains, heavy minerals, the predominance of potassium feldspar, and paucity of volcanic rock fragments in Lower Triassic sandstones suggest a varied source of plutonic, metamorphic, and sedimentary rocks. Palaeocurrent dispersal (fig. 4) and coarsening of sandstones toward the northwest in the Mt Manfred and Mt Rufus sections suggest a source area in the northwest where a variety of suitable Precambrian and lower Palacozoic basement rocks are exposed.

The predominance of intermediate to silicic volcanic grains in the Middle and Upper Triassic sequence and the occurrence of silicic tuffs in northeastern Tasmania (Bacon et al., in Clarke \& Forsyth 1989) suggest the possibility of an active volcanic source, probably to the east. Palaeocurrent data do not show any obvious trends, but the possible reversal described by Forsyih (1984) in 
TALE 5

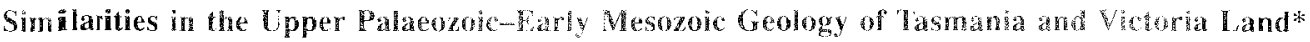

(1) Trough-shaped basins probably of fault origin.

(2) Late Carboniferous ghalals rest uncontomably above early Padaevoic grantes folded and snemorphosed sedimentary rocks with great relief locally.

(3) Sedimentary cycle began in Late Carbniterus with glacials and ended in fuande with tholeitic vulcanism.

(4) Coal measures in Permian and Midde to Upoer Triassic.

(5) Lower Triassic dominated by quatrose sandistone with little volcanic contribution.

(6) Middle and Upper Triassic dominated by volcaniclastic sandstone.

(7) Lower Triassic deposited by braided streams.

(8) Middle and Upper Triassic deposited in part by meandering strcams.

(9) Jurassic intrusion of doleric and cxtrusion of tholeitic basalt.

* Tasmanian relationships are summarised in Clarke \& Forsyth (1989) and antarctic relations in Collinson ef a. $(1986,1987)$.

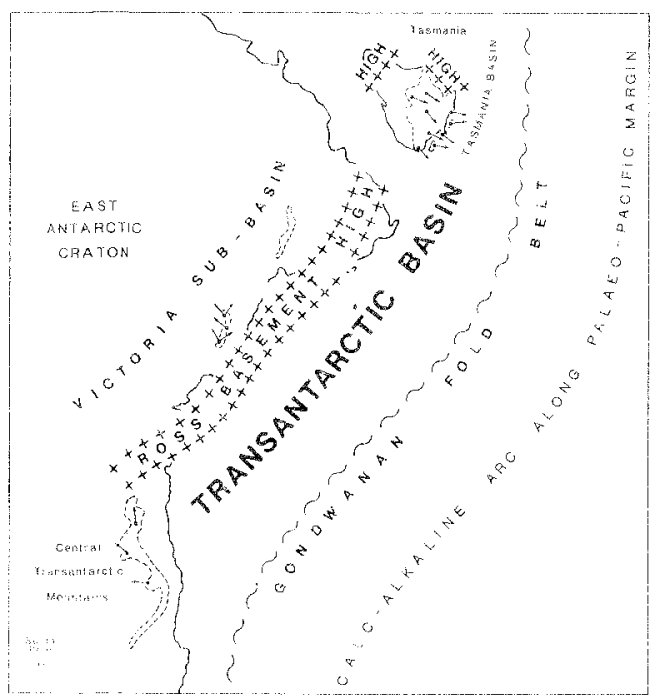

HG. 7 -- Map of palueo-Pacific nurgin of the Gondwanan supercominent including the Ross Sea coastline of East Antarrica and Tasmania. Positions of hypothetical tectonic features are based mainly on sedinenday eidenere Arrows indicate Early Triassic palaeocturent directions. For Antartica these are derived from information in Barrett \& Kohn (1975), Barrett \& Fitzgerald (1985), Barrett (1968), Collinson \& Elliot (1984), Collinson et al. (1983) and unpublished field data of the authors. the Midlands supports the existence of an easterly source. Basaltic grains in sandstones associated with basaltic lava flows in the Mt Nicholas Coal Measures near St Marys were locally derived.

Non-volcanogenic components of the upper volcaniclastic sequence suggest the continued presence of a basement source. Large clasts in the southeast and in the Midlands (Forsyth 1984, Clarke \& Forsyth 1989), including quartz feldspar porphyry and lithics containing Permian fossils, suggest a new source area to the east. Basement uplift occurred in the Late Permian or Early Triassic in northeastern Tasmania (St Marys section, fig. 3) where the uppermost Permian and Lower Triassic are missing along a disconformity (Forsyth 1989).

\section{PALAEOGEOGRAPHY}

In most Gondwanan reconstructions (e.g. DeWitt ef al. 1988), Tasmania is off the Victoria l and coast, in line with the Transantarctic Mountains (fig. 7). The Transantarcic basin, which paralleled the Transantarcic Mountains, consisted of an intracraronic sub-basin in Victorla Land and a foreland basin that were separated at times by basement highs Evidence for a foreland hasin is based on palaeocurrent dispersal and provenance relationships in the Central Transantarctic Mountains, and an intensely folded sedimentary sequence in West Antarctica (Collinson et al. 1981, Vavra et al. 1981, Collinson 1990a). The hypothetical Ross basement high blocked drainage into the Victoria sub-basin 
until Middle rriassic, when volcaniclastic sediment from a volcanic arc along the palaeo-Pacific margin spilled over the high.

A major problem in interpreting and comparing the Tasmania and Transantarctic basins is that the present exten of Triassic outcrops represents only a fraction of the ir original distribution (fig. 7). If these outcrops are part of a latger Transatiarctic--Tasmania basin, they should have similar geologic histories and it into an overall basin model. Anyone who has studied these rocks in both regions is struck by their similarity (table 5 ).

The Permian in Tasmania, except for the presence of coal measures, is different from that of Victoria Land. The marine cycles that contain an abundant shelly fauna in Tasmania are unknown in Antarctica. If these two regions are part of the same basin, Tasmania occupied the marine end of a basin that emptied into the palaeo-Pacific Ocean.

Triassic correlations between Antarctica and Tasmania are shown in figure 8 . The correlatives of the Ross and Cluan in the Transantarctic Mountains are the Feather Conglomerate and lower part of the Fremouw Formation, both of which are prominent cliff-forming, quartzose, braided stream deposits (Barrett \& Kohn 1975, Barrett \& Fitzgerald 1985 , Collinson 1990b). These formations overlie Permian coal measures along a prominent erosion surface. Palaeocurrents suggest that streams flowed northward toward the Tasmania Basin (Collinson of al. 1987). The Tiers and Brady Formations are similar to the volcaniclastic upper part of the Fremouw and Falla Formations in the central Transantarctic Mountains, and the Lashly and Section Peak Formations in Victoria Land. These units contain coal or carbonaceous shale. Palaeocurrents remain northward toward the Tasmania Basin, but a transition occurs from braided streams in the upper part of the basin to meandering streams in the lower part of the basin toward Tasmania (Collinson et al. 1987).

The hypothetical Transantarctic Tasmania basin was similar in size and many features to the Sydney-Bowen basin, which was also occupied by an extensive river system during the Triassic, and is classified as a foreland basin (Conaghan et al. 1982, Veevers et al. 1984). The Sydney-Bowen basin is bordered by the craton to the west, which contributed quartzose sandstone from the erosion of Devonian sandstones and metamorphic and granitic rocks of the Lachlan fold bell. On the east the active New England orogen contributed primarily lithic sandstone with an important penccontemporaneous volcanic component. Major drainage was axial and emptied into the palaeo-Pacific ocean.

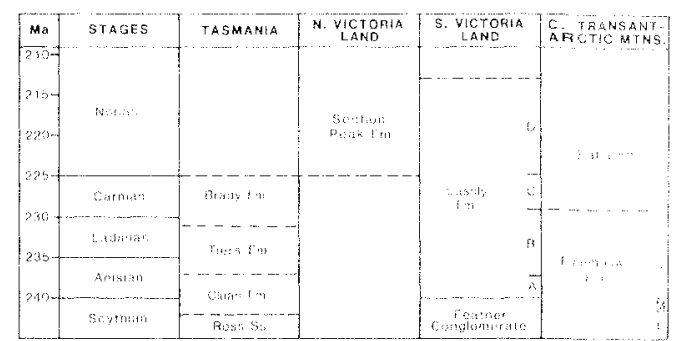

FIG. 8-- Time-stratigraphic chart comparing Tasmania to Antartica. Based on DNAG time-seale (Palmer 1983).

Using the Sydney-Bowen basin as a model, the Tasmania basin is interpreted as being part of a much larger intracratonic basin that extended landward into the Victoria Land portion of East Antarctica. This basin was bounded to the west by the craton of East Antarctica and southeastern Australia. Precambrian to lower Palaeozoic rocks in the Ross and Tasman orogens on the palaeoPacific margin of the Gondwanan craton, including basement highs in Tasmania, were the major sources of quartzose sediment in the Permian and Early Triassic. A calcalkaline volcanic arc, which bordered the Gondwanan palaeo-Pacific margin from eastern Australia to West Antarctica, was the source of volcaniclastic sediment that flooded the basin in Middle Triassic time. Other than local uplift, there is no direct evidence of a fold belt comparable to the New England or West Antarctic orogens in Tasmania or Victoria Land. However, folding, thrusting and uplift of a volcaniclastic apron of sediment from the volcanic arc along the palaeo-Pacific margin would explain the sudden flood of volcaniclastic sediments into these regions.

\section{CONCLUSIONS}

The Triassic sequence of Tasmania, best represented by the continuous stratigraphic section at Poatina, consists of a lower quartzose sandstone (Ross and lower Cluan Formations) overlain by an upper volcaniclastic sandstone and mudstone (upper Cluan, Tiers and Brady Formations). The quartzose sequence was deposited by braided streams and the volcaniclastic sequence by meandering streams. Palaeocurrent dispersal in the quartzose sequence was toward the southeast and east. Present data are insufficient to establish palaeocurrent patterns for 
the volcanclastic sofuence. The source area for the quartoose sequence was in northwestem Tasmania and the Condwanan craton west of Tasmania. The prinary source for the volcuniclastic sequence was a calcakaline volcanic are east of Tasmania along the palaeo Pacific margin. The Thiassic sequences in Tasmania and the Victoria land sector of the Transanarctic Mounains are greatly similar, suggesting that they worence part of the same, but much larger hasin. The Transantarctic Tasmania basin was similar to the Sydney-Bowen basin in size, configuration, and history. They were both foreland basins that developed on the Gondwanan craton in front of a fold-thrust belt inside the calcalkaline volcanic are that bordered the palaeoPacific margin.

\section{ACKNOWLEDGFMFNTS}

The fieldwork for this project was supported by the Geology Department, University of Tasmania; the Tasmanan Museum; the National Parks and Wildlife Service: the U.S. National Science Foundation (INT 7726877. DPP-8716414); and the Australia--USA Fulbright program. We are indebted to many individuals who helped us during the project, particularly Max Banks of the University of Tasmania, and Steve Forsyth, Mike Clarke, Clive Calver, David Jennings, and the late Noah Farmer of the Geological Survey of Tasmania. We are especially indebted to Steve Forsyth for his thorough review of the manuscript and the many helpful corrections and suggestions that he made.

\section{REFERENCES}

Bacon. C.A. \& Everard, J.L., 1981: Pyroclastics in the Upper Parmeener Super-Group, near Bicheno, eastem Tasmania. Pap. Proc. R. Sor. Tasm. 115: 29-36.

BAns. M.R., 1962: Permian System. In Spry, A.H. \& Banks, M.R, (Eds): THE GEOLOGY OF TASMANIA. I. Geol. Soc. Aust. 9(2): 189-215.

BAnes. M.R., 1973: General geology. In Banks M.R. (Ed.): THE LAKE COUNTRY OF TASMANIA. Royal Socicty of Tasmania, Hobart: 25--34.

BANks, M.R., 1978: Correlation chart for the Triassic System in Australia. Bur. Miner. Resour., Geol. Geophys. Bull. 156C: 1-13.

BAvks, M.R. \& Clarke, M.J., 1973: Tasmania Parmeener Supergroup. In Field Trip No. 1: Upper Carboniferous to Triassic rocks in southeastern Australia. 3rd Int. Gondwana Symp., Canberra: $23-46$
BAks. M.R. \& Clakk, M.I. 1987: Changes in the geography of the Tasmania batin in the bate Paleomolic in Mckentic, G.D. (Ed.) GONDWANA SIX: STRATIGRAPHY, SEDI MENTOLOGY. ANIY PALIONTOLOGY. AmG Geophys. Un. Geophys Monogr. 41: $1-14$.

BARKs, M.R. \& Nave. III., 1967: Some fomations close to the Pemo-Trassic boundary in Tasmania. Pap Pror. R. Sor Tamm 101:17 30.

BarkeT, PJ., 1968: The post-glacial Pemian and Triassic Beacon rocks in the Beardmore Glacier, central Transantareic Mountains. Antarctica. Unpubl. Pho thesis, Ohio State Univ: $510 \mathrm{pp}$.

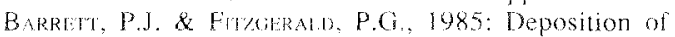
the lower Feather Conglomerate, a Permian hraided river deposit in somthem Victoria I and, Antarctica. Sediment Geol. 45: 189-208.

Barrett, P.J. \& Komn, B.P., 1975: Changing sediment transport directions from Devonian to Triassic in the Beacon Supergroup of south Victoria Land, Antarctica. In Campbell, K.S.W. (Ed.): GONDWANA GEOLOGY. ANU Press, Canberra: 15-35.

Calver, C.R. \& Castleden, R.H., 1981: Triassic basalts from Tasmania. Search 12(1-2): 40-41.

CAMP, C.L. \& BANks, M.R., 1978: A proterosuchian reptile from the Early Triassic of Tasmania. Alcheringa 2: $143-1,58$.

Clarke, M.J. \& Forsyth, S.M., 1989: Late Carboniferous-Triassic. In Burrett, C.F. \& Martin, E.L. (Eds): GEOLOGY AND MINERAL RESOURCES OF TASMANIA. GeOl. SOC. AUST. SPEC. Publ 15: $293-338$.

Collinson, J.W., 1990a: The palaeo-Pacific margin as seen from East Antarctica. In Thompson, M.R.A., Crame, J.A. \& Thomson, J.W. (Eds): GEOLOGICAL EVOLUTION OF ANTARCTICA. Cambridge University Press, Cambridge: in press.

Collinson, J.W., 1990b: Depositional setting of Late Carboniferous to Triassic biota in the Transantarctric basin. In Taylor, T.N. \& Taylor, E.L. (Eds): ANTARCTIC PALEOBOTANY, ITS ROLE IN THE RECONSTRUCTION OF GONDWANA. Springer-Verlag, New York: 1-14.

Collinson, J.W. \& El.liot, D.H., 1984: Triassic stratigraphy of the Shackleton glacier area. In Turner, M.D. \& Splettstoesser, J.F. (eds): GEOLOGY OF THE CENTRAL TRANSANTARCTK MOUNTAINS. Am. Geophys. Un. Antarct. Res. Ser. 36: 103-117.

Cominson, J.W., Kemp, N.R. \& EgGarT, J.T., 1987 : Comparison of the Triassic Gondwana sequences in the Transantarctic Mountains and Tasmania. In McKenzie, G.D. (Ed.): GONDWANA SIX: STRATIGRAPHY, SEDIMENTOLOGY AND PALEONTOLOGY. Am. GeOphys. Un. Mon. Ser. 41: $51-61$.

Coli.inson, J.W., Pennington, D.C. \& Kemp, N.R., 1983 : Sedimentary petrology of Permian-Triassic rocks in the Allan Hills, central Victoria Land Antaret. I. U.S. $18(5): 20-22$. 
Collngon, J.W. Pennington. D.C. \& Kemp. N.R., 1986: Siratigraphy and petrology of Permian and Triassic fluvial deposits in northern Victoria Land, Antarctica In Stump, E. (Ed.). GEOLOGICAL INVESTIGATIONS IN NORTHERN VICTORIA LAND. Am. GeOphYS. Un. Antart. Res. Ser. 41:211-242.

COLlinson, J.W., STANIFy, K.O. \& VAVRA, C.L.. 1981: Triassic lluvial depositional systems in the Fremouw Formation, Cumulus Hills, Antarctica. In Cresswell, M.M. \& Vella, P. (Eds): GONDWANA FIVE. A.A. Balkema, Rolterdan: $141-148$.

Connghan, P.J., Jones, J.G., MCDonnell, K.L. \& Royce, K., 1982: A dynamic fluvial model for the Sydney Basin. I. Geol. Soc' Aust. 29: 55--70.

Coscriff, J.W., 1974: Lower Triassic Temnospondyli of Tasmania. Geol. Soc. Am. Spec. Pap. 149: 134 pp.

Davidson, J.K., 1969: Upper Permian and Lower Triassic sedimentation and palynology of the La Perouse area. Unpubl, BSc (Hons) thesis, Univ. Tasm.

DeWitT, M., Jefferey, M., Bergh, H. \& Nicolaysen, L., 1988: GEOLOGICAL MAP OF SECTORS OF GONDWANA, RECONSTRUCTED TO THEIR DEPOSITION AT $150 \mathrm{Ma}$. Am. Ass. Petrol. Geol. and Univ. Witwatersrand.

Eggert, J.T., 1983: Petrology, provenance and diagenesis of quartzose and volcanic lithic Triassic fluvial sandstone, Tasmania, Australia. Unpubl. MSc thesis, Ohio State Univ.: $178 \mathrm{pp}$.

Folk, R.L., ANorews, P.B. \& Lew!s, D.W., 1970: Detrital sedimentary rock classification and nomenclature for use in New Zealand. N.Z. I. Geol. Geophys. 13(4): 937-968.
Forsyri, S.M.. 1980: Preliminary palynological report on Upper Paimeener Super-Group rocks interbedded with basal at Webber Falls. Unpubl. Rep. Tasm. Dep. Mines.

Forsyth, S.M., 1984: Oatlands. Geol. Atlas 1.50 $000 \mathrm{Se}$. Explan. Rep. Sheet 68 (8313S). Tasm. Dep. Mines: $182 \mathrm{pp}$.

Forsyth, S.M., 1989: Interlaken. Geol. Atlas /:50 ooo Ser. Explan. Rep. Sheel 61 (8313N). Tasm. Dep. Mines: $90 \mathrm{pP}$

H.t, G.E.A., 1962: Triassic Systen. In Spry, A.H. \& Banks, M.R. (eds): THE GEOLOCY OF TASMANIA J. Geol SOC. Aust 9: 217-231.

MoKellar, J.B.A., 1957: Geology of portion of the Western Tiers. Rec. Q. Vict. Mus. N.S. 7: 1-13.

PAIMER, A.R., 1983: THE DECADE OF NORTH AMERICAN GEOLOGY 1983 TIME SCALE. Geological Society of America.

Playford, G., 1965: Plant microfossils from Triassic sediments near Poatina, Tasmania. J. Geol. Soc. Aust. 12(2): 173-207.

Turner, N.J. \& Calver, C.R., 1987: St Marys. Geol. Atias I.50 000 Ser. Explan. Rep. Sheel $49(8514 \mathrm{~N})$. Tasm. Dep. Mines: 159 pp.

Vavra, C.L., Stanley, K.O. \& Collinsor, J.W., 1981 : Provename and alteration of Triassic Fremouw Formation, central Transantarctic Mountains. In Cresswell, M.M. \& Vella, P. (Eds): GONDWANA FIVE. A.A. Balkema, Rorterdam: 149-153.

VeEvers, J.J. (ED.). 1984: PHANEROZOIC EARTH HISTORY OF AUSTRALIA. Clarendon Press, Oxford: 418 pp.

(acepted 4 May 1990) 